\title{
ACCUMULATION IN THE REGION OF WILKES, WILKES LAND, ANTARCTICA
}

\author{
By H. P. Black* and W. Budd $\dagger$ \\ (Antarctic Division, Department of External Affairs, Melbourne, Australia)
}

\begin{abstract}
Carrying on from the work initiated over the I.G.Y. period by the United States glaciological parties at Wilkes (cf. Hollin and Cameron, ig6r ), members of the Australian National Antarctic Research Expeditions have continued accumulation stake measurements to $80 \mathrm{~km}$. inland on the plateau (lat. $66^{\circ} 3 \mathrm{I}^{\prime} \mathrm{S}$.) and extended them south $480 \mathrm{~km}$. (to lat. $7 \mathrm{I}^{\circ} \mathrm{S}$.). These stake measurements, supplemented by pit data and surface observations, supply a comprehensive account of the accumulation in this region; how it builds up during the year, how it varies from year to year and how it is affected by topography.
\end{abstract}

RÉsumé. Continuant le travail commencé au cours de la période de l'A.G.I. par les équipes glaciologiques des États-Unis à Wilkes (cf. Hollin and Cameron, ig6i), les Membres des "Australian National Antarctic Research Expeditions"' ont continué les mesures d'accumulation à l'aide de balises jusqu'à 80 km à l'intérieur sur le plateau $\left(66^{\circ} 3 \mathrm{I}^{\prime}\right.$ lat. S) et les ont étendues plus au Sud jusqu'à $480 \mathrm{~km}$ ( $7 \mathrm{I}^{\circ}$ lat. S). Ces mesures à partir de balises, complètées par les observations de surface et des puits, fournissent des données complètes sur l'accumulation de cette région: sa répartition au cours de l'année, sa variation d'année en année et les effets des caractères topographiques.

Zusammenfassung. Anknüpfend an die Untersuchungen US-amerikanischer Glaziologen während des IGJ in Wilkes Land (vergl. Hollin and Cameron, I96I) haben Teilnehmer der Australian National Antarctic Research Expeditions Messungen an Akkumulationspegeln bis $80 \mathrm{~km}$ landeinwärts auf dem Polplateau (Br. $66^{\circ} 3^{\prime} \mathrm{S}$ ) fortgeführt und $480 \mathrm{~km}$ nach Süden (bis Br. $71^{\circ} \mathrm{S}$ ) ausgedehnt. Diese Messungen, ergänzt durch Beobachtungen in Schächten und auf der Oberfläche, vermitteln ein umfassendes Bild vom Schneeauftrag des Gebietes: sein Anwachsen im Jahresablauf, seine Schwankungen von Jahr zu Jahr und seine Abhängigkeit von der Gestalt des Geländes.

\section{Plateau Topography}

Wilkes is situated on a rock peninsula, Io m. elevation, at lat. $66^{\circ}$ I $5.5^{\prime} \mathrm{S}$., long. I $10^{\circ}$ $3^{\mathrm{I}} \cdot 5^{\prime}$ E. (Fig. I). From here the ice plateau rises steeply at first then more gradually farther inland (Fig. 5). A satellite station, $\mathrm{S}_{2}$, is situated $80 \mathrm{~km}$. east-south-east of Wilkes at an elevation of $\mathrm{I}, \mathrm{I} 66 \mathrm{~m}$. in lat. $66^{\circ} 3 \mathrm{I}^{\prime} \mathrm{S}$., long. $\mathrm{I} 12^{\circ} \mathrm{I} 2^{\prime} \mathrm{E}$.

South of station $\mathrm{S}_{2}$ the ice cap continues to rise to about $\mathrm{I}, 230 \mathrm{~m}$. at $29 \mathrm{~km}$. south, then falls to $880 \mathrm{~m}$. at $90 \mathrm{~km}$. south. From there the plateau rises gradually but less steeply to $2,990 \mathrm{~m}$. at $48 \mathrm{o} \mathrm{km}$. south of station $\mathrm{S}_{2}$ in lat. $7 \mathrm{I}^{\circ} \mathrm{oo}^{\prime} \mathrm{S}$. Plateau slopes measured in I $96 \mathrm{I}$ and further elevations obtained in March 1962 indicate that the Budd Coast has a high region with a central dome over $\mathrm{I}, 500 \mathrm{~m}$. in elevation at about lat. $66^{\circ} 33^{\prime} \mathrm{S}$., long. $113^{\circ} \mathrm{oo}^{\prime} \mathrm{E}$.

To the south of this high region there is a low region less than $900 \mathrm{~m}$. in elevation extending from the Totten Glacier to the Vanderford and John Quincy Adams Glaciers. Seismic soundings indicate that the bedrock surface reaches $3,200 \mathrm{~m}$. below sea-level in this region (Jewell, unpublished).

It will be seen that this topographical depression has a marked influence on the accumulation in the region.

\section{Stake Systems and Measurements}

\section{Wilkes local area}

In November 1957 a set of more than 35 stakes was placed from the rock peninsula coast, up over the steep ice ramp to about ${ }_{1} 3 \mathrm{~km}$. inland on the plateau, at an elevation of $380 \mathrm{~m}$. (Cameron and others, 1959). Except for several stakes which melted out in the summer months and had to be replaced, this stake system has been measured regularly until i 962 . In 1959 the accumulation stakes were hollow or split bamboo. These tended to bend or

* Officer-in-Charge, Wilkes, Australian National Antarctic Research Expeditions, 1960.

† Glaciologist, Wilkes, Australian National Antarctic Research Expeditions, 1961 . 
break in strong winds and therefore they were gradually replaced by solid cane stakes $2.5 \mathrm{~cm}$. in diameter. All these new stakes were painted white. This was found to greatly reduce melt water forming around them in summer.

Although the relative change in plateau surface has been recorded on this stake system since 1957 , the variation in net accumulation is difficult to determine precisely, because of the

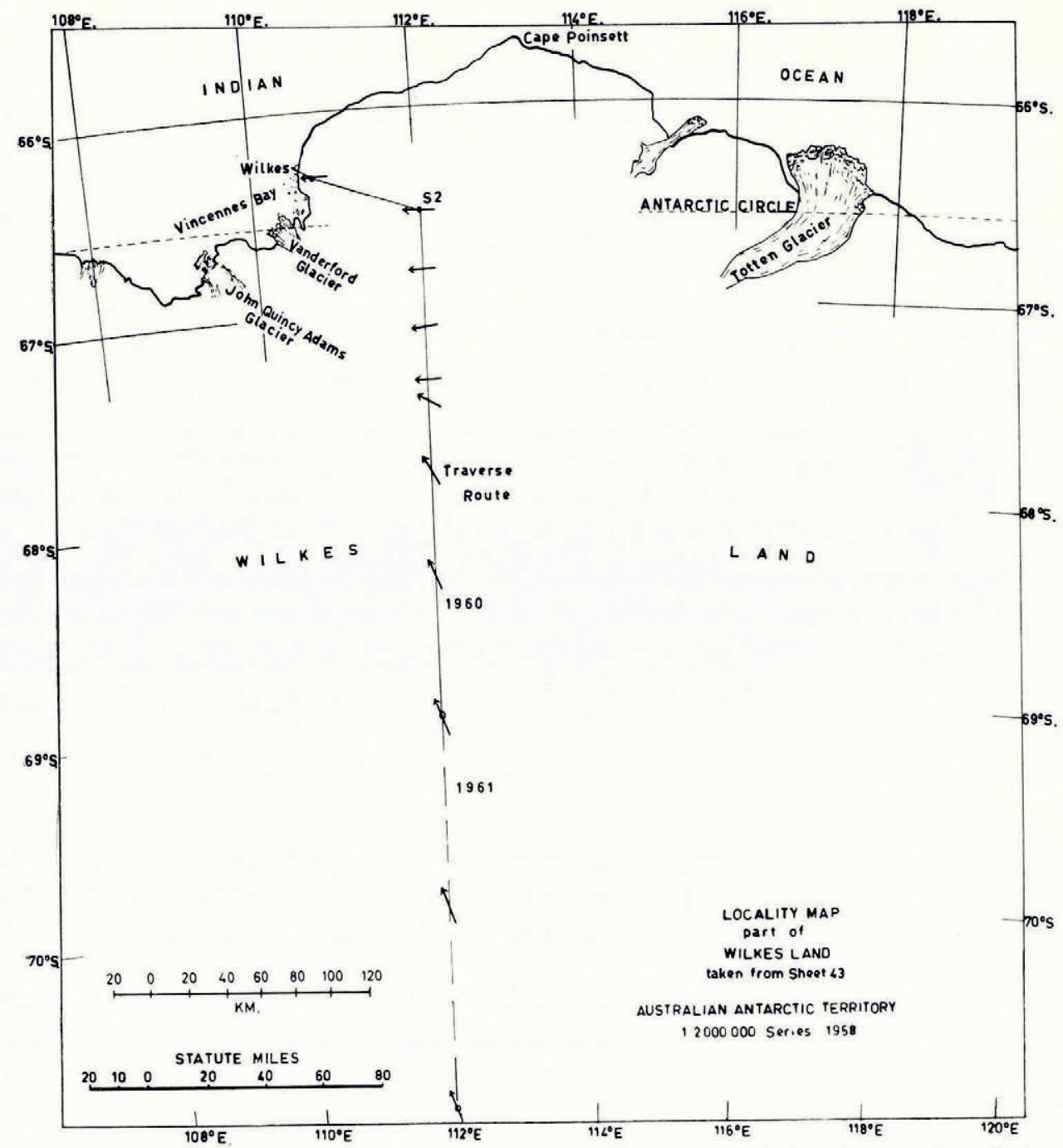

Fig. I. Location map of Wilkes and traverse routes of 1960 and 1961 . The arrows marked along the route indicate the prevailing wind directions as measured from the predominant sastrugi orientations of 1961 (cf. Mather, $\left.1962, p .{ }^{6} 69-7 I\right)$

extensive metamorphism taking place at the surface. This metamorphism has been described in detail by Hollin and others (196r, p. 194-95). Not only does the relative height of the firn surface change but also the density of the snow at and near the surface changes due to such processes as wind packing, melting, refreezing, ice formation and crystal growth. Hence, in order to determine the net water equivalent accumulation it would be necessary to keep a stratigraphic and density record for each stake throughout the year. 
As this was impracticable the procedure adopted for I96o and I96I was to measure the height of the stake relative to the surface and also to the ice and record the density and type of surface snow. Often there were several different layers of snow above the ice and their depths and densities had to be recorded separately. The ice itself changed little except near the surface where the density was found to range from $0.65 \mathrm{~g} . \mathrm{cm} .^{-3}$, for the small-grained "white" ice containing large bubbles, to $0.85 \mathrm{~g} . \mathrm{cm} .{ }^{-3}$ for the large-grained "blue" ice containing small bubbles.

During 1959 few density measurements were made. However, for each stake at every measurement the type of snow at the surface was recorded by a standard classification ranging from freshly fallen snow to ice. In order to obtain an estimate of the change in net waterequivalent accumulation during this year, density values have been assigned to the various types of snow (to the nearest $0 \cdot 05 \mathrm{~g} . \mathrm{cm}^{-3}$ ) from the corresponding information, including densities, gathered during 1960 and 1961 .

Measurements of the 35 stake system were made monthly in 1959 and r 960 and fortnightly in $196 \mathrm{r}$.

\section{Station $S_{2}$ trail}

Inland from the local area near Wilkes, a set of 8 stakes was placed in October I 957 at $8 \mathrm{~km}$. intervals along the route to station $\mathrm{S}_{2}$ (Cameron and others, r959). With these stakes no summer melt-out was encountered, and densities from pit and surface measurements were more accurately determined. The thickness and frequency of ice bands were found to gradually decrease with distance inland. Beyond station $\mathrm{S}_{2}$ no ice lenses or bands were encountered in pits; only numerous fine wind crusts were observed. A complete analysis of pit stratigraphy will be published at a later date.

From the pit studies it has been found that the snow is strongly wind packed and hard, with densities ranging from 0.38 to $0.46 \mathrm{~g} . \mathrm{cm} \cdot{ }^{-3}$ in different layers. The average density, however, showed no significant increase from the surface to $2.0 \mathrm{~m}$. depth (corresponding to more than $4 \mathrm{yr}$. accumulation). This indicates that the effect of compaction to this depth is negligible. The average density to $2 \cdot 0 \mathrm{~m}$. depth for the whole route was $0 \cdot 4 \mathrm{I} \mathrm{g} . \mathrm{cm} .^{-3}$ and this has been used as a constant conversion factor for snow accumulation to water equivalent.

The accumulation results have been calculated from the following measurements: two in I 957 , eleven in $195^{8}$, four in 1959 , two in 1960 and seven in $1961-62$.

\section{Station $\mathrm{S}_{2}$}

At station $\mathrm{S}_{2}$ two sets of stakes were used:

(i) A set of three $5 \mathrm{~cm}$. by $5 \mathrm{~cm}$. U.S. Weather Bureau stakes was placed in 1957 , and a large number of measurements were made on them until January i 962 , although they have been replaced several times (to $200 \mathrm{~m}$. across wind from the station) to avoid the station drift. These stakes give a detailed picture of how the accumulation rate has varied with time, but they cannot be taken as representative of the area as a whole.

(ii) Station $\mathrm{S}_{2}$ strain grid. A set of 12 relative-movement stakes $(3 \mathrm{~cm}$. diameter) were placed over a $20 \mathrm{~km}^{2}$ area at station $\mathrm{S}_{2}$ in March 1957 (Cameron and others, 1959). Although fewer readings are available for this system than the above stakes, they serve to give a more accurate estimate of the mean accumulation of the region and also its variation over this area.

The following measurements were made: four in 1957, three in 1958, one in 1959, one in 1960 and six in $196 \mathrm{I}-62$.

Cameron and others (1959, p. 66) noted that the mean net accumulation rate measured from the three U.S. Weather Bureau stakes was higher than that of the mean of the relative movement network. It was suggested that this may be due to the influence of the station or to 
the larger cross-section of the U.S. Weather Bureau stakes. However, it will be seen below that in view of the variability in net accumulation rates among the stakes of the relative movement network, due to slight topographic differences, the net accumulation rate at any one position (such as at station $\mathrm{S}_{2}$ ) cannot be expected to be representative of the area as a whole.

\section{South of station $\mathrm{S}_{2}$}

In November I960 a total of 180 stakes were placed over a distance of 180 miles $(290 \mathrm{~km}$.) due south from station $\mathrm{S}_{2}$ to lat. $69^{\circ} \mathrm{S}$. The interval between successive stakes was I statute mile ( $1.6 \mathrm{~km}$.), and the stakes were numbered $\mathrm{I}$ to $\mathrm{I} 80$ commencing at station $\mathrm{S}_{2}$.

During I96I stakes I to I 20 were remeasured in February and again in March, and stakes I to I80 were remeasured in November and again in December. In December i 96 I the stake line was extended to 300 miles $\left(480 \mathrm{~km}\right.$.) south of station $\mathrm{S}_{2}$, as far as lat. $7 \mathrm{I}^{\circ} \mathrm{S}$., for remeasurement in 1962 and 1963 .

The properties of the firn were studied by a series of pit and surface measurements. In November $196 \mathrm{I}$ eighteen $2 \mathrm{~m}$. pits were dug next to an accumulation stake, one each $32 \mathrm{~km}$. from Wilkes to station $\mathrm{S}_{2}$ and $480 \mathrm{~km}$. south of station $\mathrm{S}_{2}$. Surface density was also recorded each $8 \mathrm{~km}$. Because of the high accumulation over most of the route, the average densities of the annual layer (sometimes in excess of $2 \mathrm{~m}$.) obtained from the pits were needed for water equivalent calculations rather than the more closely spaced surface density observations. The firn densities varied from an average of $0.44 \mathrm{~g} . \mathrm{cm} \cdot{ }^{-3}$ in hard wind-packed winter layers to $0.37 \mathrm{~g} . \mathrm{cm}^{-3}$ in softer summer layers. These values were slightly higher for deeper layers more than one year old.

\section{RESULTS}

\section{Wilkes local area}

(a) Accumulation during the year: The pattern of accumulation during the year appears to depend largely upon the pattern of precipitation. The difficulties of measuring precipitation in Antarctica are well known. However, at Wilkes during ig6 I most of the precipitation as recorded daily from the snow gauges occurred with light winds and when totalled over a period without strong winds agreed closely with the local increase in accumulation. Stronger winds following soon after removed a large proportion of this new snow, the remainder becoming packed hard. This resulted in a net accumulation which increased with heavy precipitation but only as a proportion of it. This pattern is illustrated in Figure 2. When precipitation was small ablation still went on so that a decrease in net accumulation resulted. The difference between cumulative precipitation and net accumulation in Figure 2 represents the cumulative loss. Drift transport by wind, sublimation and melt contributed to the ablation. Of these only drift transport has been directly measured. The measurements of drift transport carried out at Wilkes in 1959 (Dingle and Radok, 196r) were extended in r96o and I96r. Analysis of the results, not yet completed, will aim in particular at estimating the loss of snow by wind from Wilkes and inland as far as station $\mathrm{S}_{2}$.

(b) Accumulation in different years: For the years 1957 and $195^{8}$ several points are noted from Hollin and others ( $196 \mathrm{r}$ ).

First, for the summer of $1957-58$ ablation was extensive, melt streams were observed below $150 \mathrm{~m}$. elevation, and the zone of ablation extended to $230 \mathrm{~m}$.

Secondly, "accumulation appears to have been relatively small during the first half of I958". This has also been a feature of later years and so may be a general result for this region.

Thirdly, "ablation in the summer of $195^{8-59}$ was far less than that of 1957-58. Few streams were observed and the whole of the area down to sea-level remained in the accumu- 
lation zone". Average net accumulation from 24 February 1958 to 2 February I959 for stakes 402 to 429 (at elevations of approximately roo to $380 \mathrm{~m}$.) was about ro g. $\mathrm{cm} .^{-2}$.

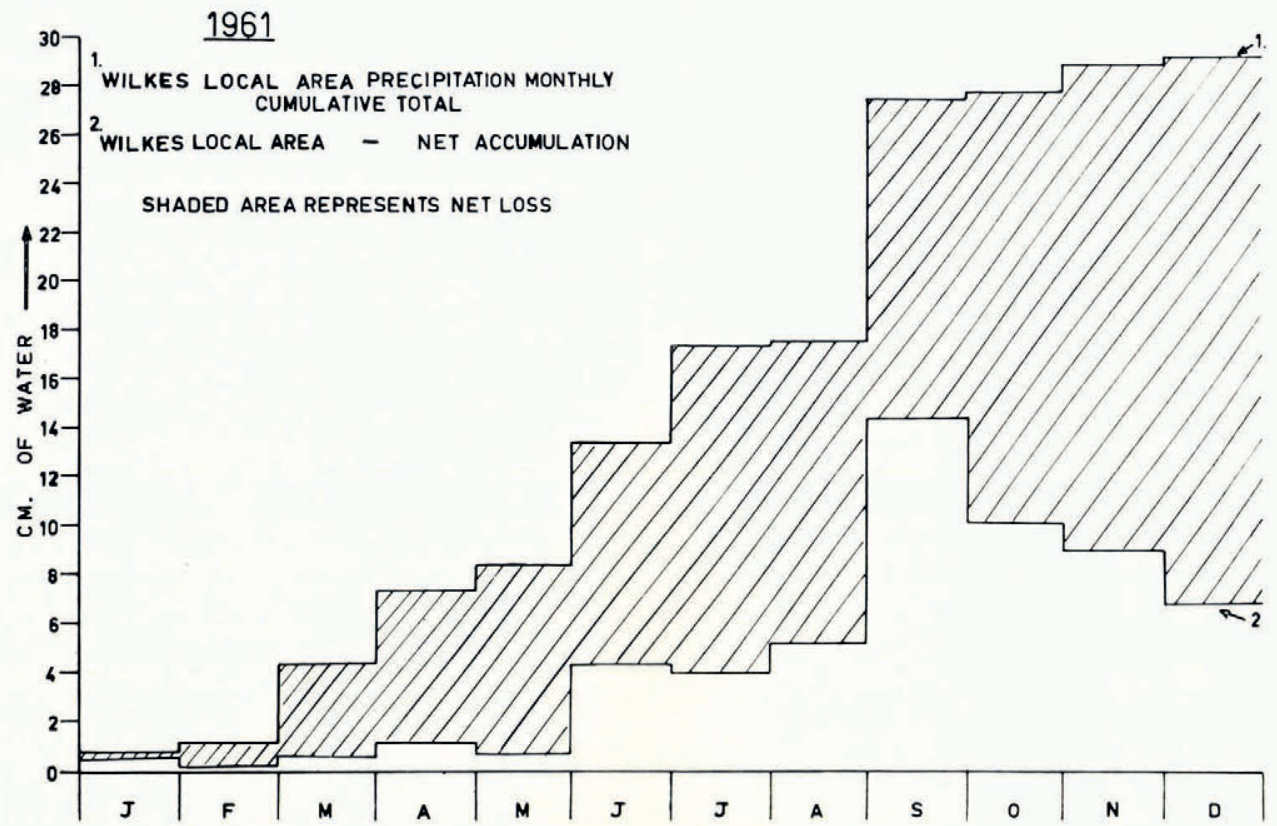

Fig. 2. (I) Wilkes precipitation for 1961 ; cumulative monthly totals. (2) Wilkes local area average net accumulation. The difference between the two values represents the cumulative net loss

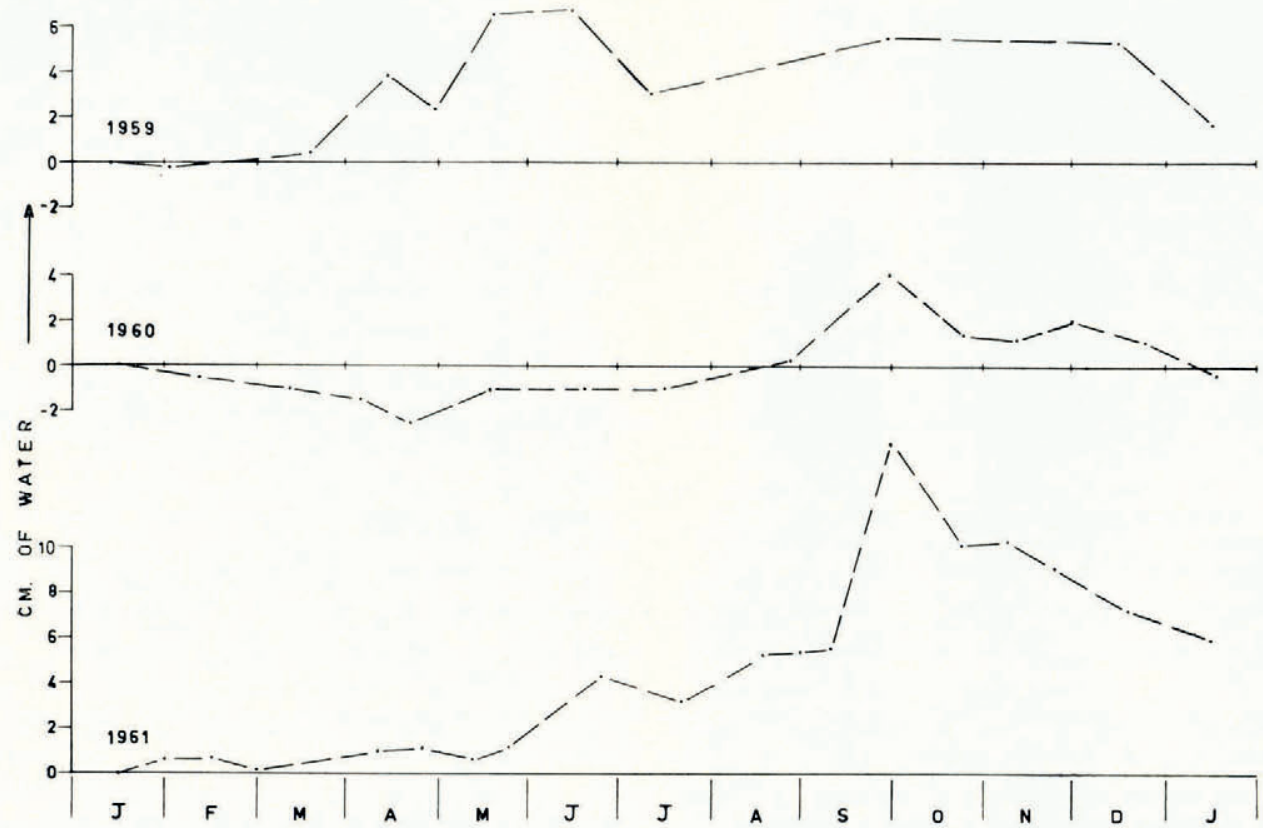

Fig. 3. Wilkes local area average net accumulation for $1959-6 \mathrm{I}$ 
For the years 1959 to I96r the pattern of net accumulation is illustrated in Figure 3 . The general trends appear to be: ablation or little gain by April-May, then a steady build-up to a maximum about September-October, after which summer ablation sets in and net loss continues until the following March to May.

In I96 I the average net accumulation from 15 January was only $0.6 \mathrm{~g} . \mathrm{cm} .^{-2}$ by May, after which a continual build-up occurred to a maximum of I I $5 \mathrm{~g} . \mathrm{cm} .^{-2}$ in September, then ablating to $6 \cdot 0 \mathrm{~g} . \mathrm{cm} .^{-2}$ by 15 January 1962 .

The corresponding figures from I 5 January I 960 are $-2.5 \mathrm{~g} . \mathrm{cm}^{-2}$ by April to $+4 \cdot \mathrm{I}$ g. $\mathrm{cm}^{-2}$ in September and $-0.3 \mathrm{~g} . \mathrm{cm} .^{-2}$ by January I $96 \mathrm{I}$.

(c) The extent of the ablation zone: In 1960 the net ablation zone extended to about $260 \mathrm{~m}$. elevation-similar to the extent observed in 1957. The average net accumulation for the $3 \mathrm{~km}$. below this line was $-2 \cdot 0 \mathrm{~g} . \mathrm{cm} .^{-2}$ compared with $+2 \cdot 5 \mathrm{~g} . \mathrm{cm} .^{-2}$ for the $3 \mathrm{~km}$. immediately above it. However, the ablation zone has no well-defined limit, for it gradually merges into the accumulation zone and to different extents in different years. In I96r, as in I958, there was a positive net accumulation over the whole of the local area extending down to sea-level.

From this it is seen that the resultant change in the plateau surface in this area over $5 \mathrm{yr}$. has been small, with annual net accumulation fluctuating from positive to negative in different years.

\section{Wilkes to station $\mathrm{S}_{2}$}

The trail stakes to station $\mathrm{S}_{2}$ show a steady build-up of accumulation since 1957, with average annual net accumulation from $195^{8}$ to I96I of: $13 \cdot 5,8 \cdot 2,8 \cdot 8$ and $10 \cdot 1 \mathrm{~g} . \mathrm{cm} \cdot{ }^{-2}$, giving an average rate of $10.2 \mathrm{~g} . \mathrm{cm}^{-2}$ per annum over the $4 \mathrm{yr}$.

The pattern of accumulation during the year is characterized by a rapid build-up from autumn to spring and slight loss from December to March, e.g. from December ig6o there was a loss of $\mathrm{I} \cdot 6 \mathrm{~cm}$. of water by March I $96 \mathrm{I}$, then a gain of I I $\cdot 0 \mathrm{~g} . \mathrm{cm} .^{-2}$ to December I 96 I and a loss of $\mathrm{I} \cdot 2 \mathrm{~g} . \mathrm{cm} .^{-2}$ by March $\mathrm{I}_{962}$. This general pattern is similar to that at station $\mathrm{S}_{2}$ which is discussed in the next section.

The variation in the average net accumulation rate $\left(\mathrm{IO} \cdot \mathrm{I} \mathrm{g.} \mathrm{cm} .{ }^{-2}\right)$ for different stakes along this profile is small. The standard deviation for the eight stakes was $\mathrm{I} \cdot 3 \mathrm{~g}$. $\mathrm{cm} \cdot{ }^{-2}$. The mean rate of net accumulation for the four stakes nearest the coast varied from $0 \cdot 89$ to $0 \cdot 84$ times that of the four stakes farther inland from I959 to 196r. Application of Student's $t$ test to the difference between the two means shows this to be quite significant. Hence, the rate of net accumulation increases slightly with elevation and distance inland. This is in agreement with the results found for the coast and for station $\mathrm{S}_{2}$.

\section{Station $S_{2}(80 \mathrm{~km}$. inland)}

The net accumulation at station $\mathrm{S}_{2}$ from $\mathrm{I} 957$ to $\mathrm{I} 962$ is illustrated in Figure 4. This shows that net accumulation has been almost linear with time, except for the cyclic variation during a particular year. This variation during the year appears to be similar from year to year, and shows an autumn-spring build-up which causes an excess of snow in spring, followed by a summer ablation causing a deficiency from the average rate, late summer to autumn. Variations from the overall linearity follow from variations in annual net accumulation, e.g. as with the more coastal regions the net accumulation of $195^{8}$ was slightly higher than for other years.

The average rate over the whole period for the three stakes was $\mathrm{i} 6 \cdot \mathrm{og} . \mathrm{cm} .^{-2}$. This value, however, cannot be considered representative of the area because of the possible influence of drifts caused by the station. For a measure of the average accumulation of the area the results of the grid system are needed. 
The $35 \mathrm{~m}$. pit at station $\mathrm{S}_{2}$ (Cameron and others, 1959) gave the average accumulation rate from $\mathrm{I} 783$ to 1957 as $\mathrm{I} 3 \cdot 3 \mathrm{~g} . \mathrm{cm} .^{-2}$, with five-year means varying from $9 \cdot 0$ to $17 \cdot 4 \mathrm{~g} . \mathrm{cm} .^{-2}$.

The strain grid of $\mathrm{I} 2$ stakes gives an average rate of accumulation over $20 \mathrm{~km}^{2}$ ( 1957 to I962) of $14.2 \mathrm{~g} . \mathrm{cm} \cdot .^{-2}$, with a standard deviation of $3 \cdot \mathrm{I} \mathrm{g} . \mathrm{cm} .^{-2}$. This relatively large variation among stakes, in contrast to that of the trail to station $\mathrm{S}_{2}$, is not a random variation due, for example, to sastrugi (which are comparatively small in this region) but more a

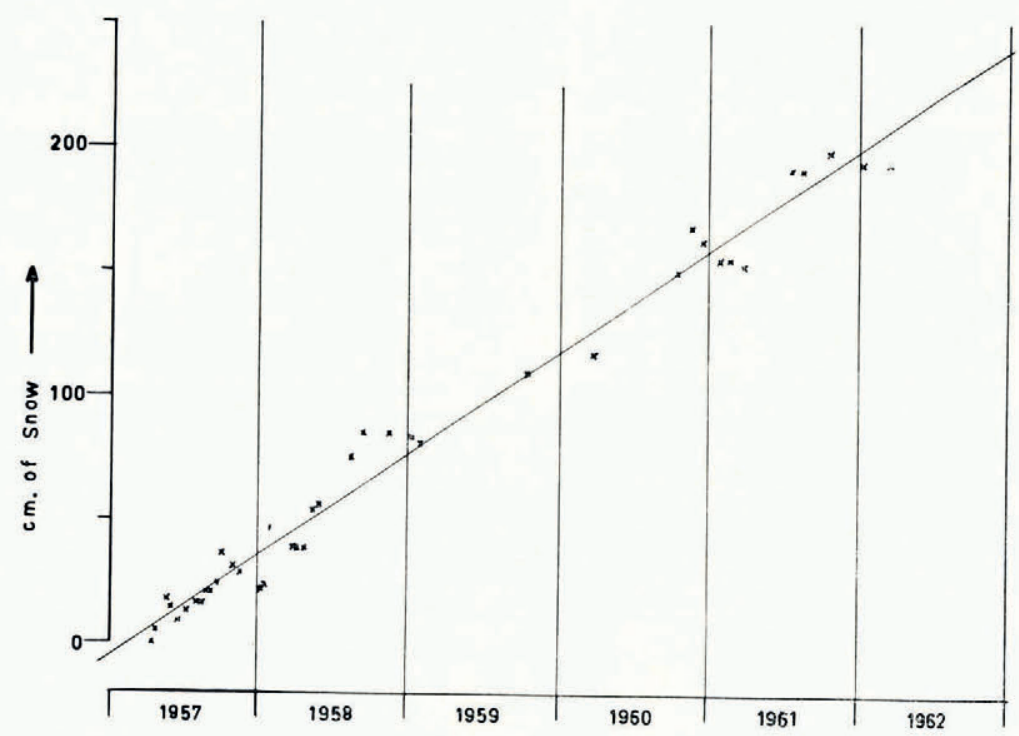

Fig. 4. Average net snow accumulation at station $S_{2}$, from 1957 to 1962 , measured from the three $5 \mathrm{~cm}$. $\times 5 \mathrm{~cm}$. stakes. The straight line is the least squares regression line for net accumulation with time. The actual net accumulation total tends to be below this line in late summer and above it over late winter and spring

property of position. This follows from the result that the proportional differences in the net accumulation rates for different stakes has varied only slightly over the period. Although the maximum slope in this area is less than $40 \mathrm{~min}$. of arc, slight variations in surface topography appear to be responsible for the variation in the net accumulation rates. This is brought out more clearly by a closer examination of the accumulation figures for the strain-grid stakes.

The network consists of four inner stakes surrounded by eight outer stakes. The distance between neighbouring stakes is about $\mathrm{I} \cdot 5 \mathrm{~km}$. For the inner four stakes, A, B, C and D, the relative elevations of their surrounding neighbours are available. From these, estimates of the average slope of the line of greatest slope through each of $\mathrm{B}, \mathrm{C}$ and $\mathrm{D}$ have been made, together with the degree of convexity or concavity. The curvature was assumed to be the average of the increases in slope going through the point in the direction of maximum slope and across this slope. (Stake A was omitted because it is in the station area.)

For each of these stakes the ratio of its accumulation rate to that of the mean of the network is listed in Table I for periods from r 957 to 1962 , together with the slope and curvature of the stake position.

The accumulation rate has been consistently greatest for stake $\mathrm{C}$, in a relative flat concave position, and least for stake D in a steeper convex position. For position B, with the same curvature as $\mathrm{C}$ but where the slope is greater, the accumulation rate has been midway between that of $\mathrm{C}$ and $\mathrm{D}$. 
From this it appears that both slope and curvature may play an important part in the topographical effect on accumulation rate. This becomes more evident south of station $\mathrm{S}_{2}$ where the topographical variations and the corresponding net accumulation rate variations are much larger.

Table I. Relative Accumulation Rates and Topography in the Region of Station S2

\begin{tabular}{|c|c|c|c|}
\hline Stake & C & B & $D$ \\
\hline Deviation from mean slope $\left(27^{\prime}\right)$ & $-1 \cdot 4^{\prime}$ & $+\mathrm{I} \cdot 6^{\prime}$ & $+0 \cdot 6^{\prime}$ \\
\hline Convexity $(-)$ or concavity $(+)(\mathrm{min} . / \mathrm{mile})$ & $+7 \cdot 0$ & $+7 \cdot 0$ & $-18 \cdot 7$ \\
\hline Relative accumulation rate from & & & \\
\hline 20 March 1957 to 18 January $195^{8}$ & $1 \cdot 24$ & $1 \cdot 17$ & $0 \cdot 49$ \\
\hline I8 January I $95^{8}$ to Io January 1959 & $\mathrm{I} \cdot 20$ & $0 \cdot 82$ & $0 \cdot 4^{2}$ \\
\hline Io January I 959 to 1 March I96I & $\mathrm{I} \cdot \mathrm{OI}$ & $0 \cdot 94$ & $0 \cdot 83$ \\
\hline I March ig61 to 2 January 1962 & $\mathrm{I} \cdot 26$ & $1 \cdot 11$ & 0.69 \\
\hline 20 March 1957 to 2 January 1962 & $1 \cdot 13$ & $0 \cdot 99$ & 0.67 \\
\hline
\end{tabular}

\section{South of station $S_{2}$}

For this region only one year's data are available at present. Also, because of the high accumulation the pits did not extend far into the past, so that the results cannot be taken as indicative of general trends as the above longer-term data. However, where the pits covered two or more years the pattern shows accumulation values of the same order as measured at the stake next to the pit from November i96o to November/December 196r. Stakes o to $5^{0}$ which were remeasured in March 1962 and gave an average of $13 . \mathrm{I}$. $\mathrm{cm}^{-2}$ net accumulation from November I $96 \mathrm{I}$, compared with $13.7 \mathrm{~g} . \mathrm{cm} .^{-2}$ for these stakes over the similar period during $1960-6 \mathrm{r}$. This suggests the same order of accumulation may be expected for 1962 .

The average net accumulation over the whole profile from Wilkes to station $\mathrm{S}_{2}$ and $480 \mathrm{~km}$. south was found to be $33 \mathrm{~g} . \mathrm{cm} .^{-2}$. This is of similar magnitude to that recorded south of Dumont d'Urville (Lorius, I 962), and south of Mirny (Dolgushin, I96r). However, south of station $\mathrm{S}_{2}$ there is a region for which the profile over $200 \mathrm{~km}$. gave an average net accumulation in excess of $5^{6} \mathrm{~g} . \mathrm{cm} \cdot{ }^{-2}$.

Stake tops were originally $214 \mathrm{~cm}$. above the surface; after 12 months several stakes were covered completely and many others protruded by only a few centimetres. The snow in this region was very hard and wind packed with an average density of $0 \cdot 4^{2} \mathrm{~g} . \mathrm{cm} \cdot{ }^{-3}$. Hard wind-eroded sastrugi often reached heights of $\mathrm{I} \cdot 5 \mathrm{~m}$.

The most remarkable feature of the accumulation south of station $\mathrm{S}_{2}$ is its apparent variation with topography on both major and minor scales.

(a) The variation of accumulation with major topography (illustrated in Figure 5): South of station $\mathrm{S}_{2}$, as the elevation increases to a high region between 20 and $29 \mathrm{~km}$., the average annual net accumulation (from November ig6o to November ig6r) decreases to $5 \mathrm{~cm}$. of water. From here southwards the accumulation increases rapidly in the large trough about $90 \mathrm{~km}$. south and up the following slope to averages of $80 \mathrm{~cm}$. of water equivalent. This average gradually decreases to $30 \mathrm{~cm}$. of water at $290 \mathrm{~km}$. south of station $\mathrm{S}_{2}$.

From 290 to $480 \mathrm{~km}$. south of station $\mathrm{S}_{2}$ the pit data indicate a continued steady decrease to $20 \mathrm{~g}$. $\mathrm{cm} .^{-2}$ per annum. Here, at lat. $70^{\circ} 52^{\prime} \mathrm{S}$., the plateau elevation reaches $2,990 \mathrm{~m}$. and the plateau slope is less than Io min. of arc in any direction. Ram-hardness values to $4 \mathrm{~m}$. depth and lack of sastrugi indicate that this region is beyond the zone of strong surface winds.

The variation in accumulation rate during the year (for stakes o to 120 ) to $192 \mathrm{~km}$. south of station $\mathrm{S}_{2}$ is illustrated in Figure 6. Over the summer period, November (1960) to March ( $196 \mathrm{I}$ ), the high region $20 \mathrm{~km}$. south of station $\mathrm{S}_{2}$ showed an average slight ablation of approximately I g. $\mathrm{cm}^{-2}$. Farther south there was a substantial build-up over this period, 
the average overall rate being $\mathrm{I} \cdot 7 \mathrm{~g} . \mathrm{cm} .^{-2} /$ month. This can be compared with $2 \cdot 8 \mathrm{~g} . \mathrm{cm} \cdot{ }^{-2} /$ month during March, $2 \cdot 3 \mathrm{~g} . \mathrm{cm} .^{-2} /$ month from March I96I to November I96I, and I.8 g. cm. ${ }^{-2} /$ month from November I961 to January i 962 .

(b) Variation with minor topography: The elevation profile for each position in the region 90 to $300 \mathrm{~km}$. south of station $\mathrm{S}_{2}$ shows, superimposed upon the steady slope (seen in Figure 5),

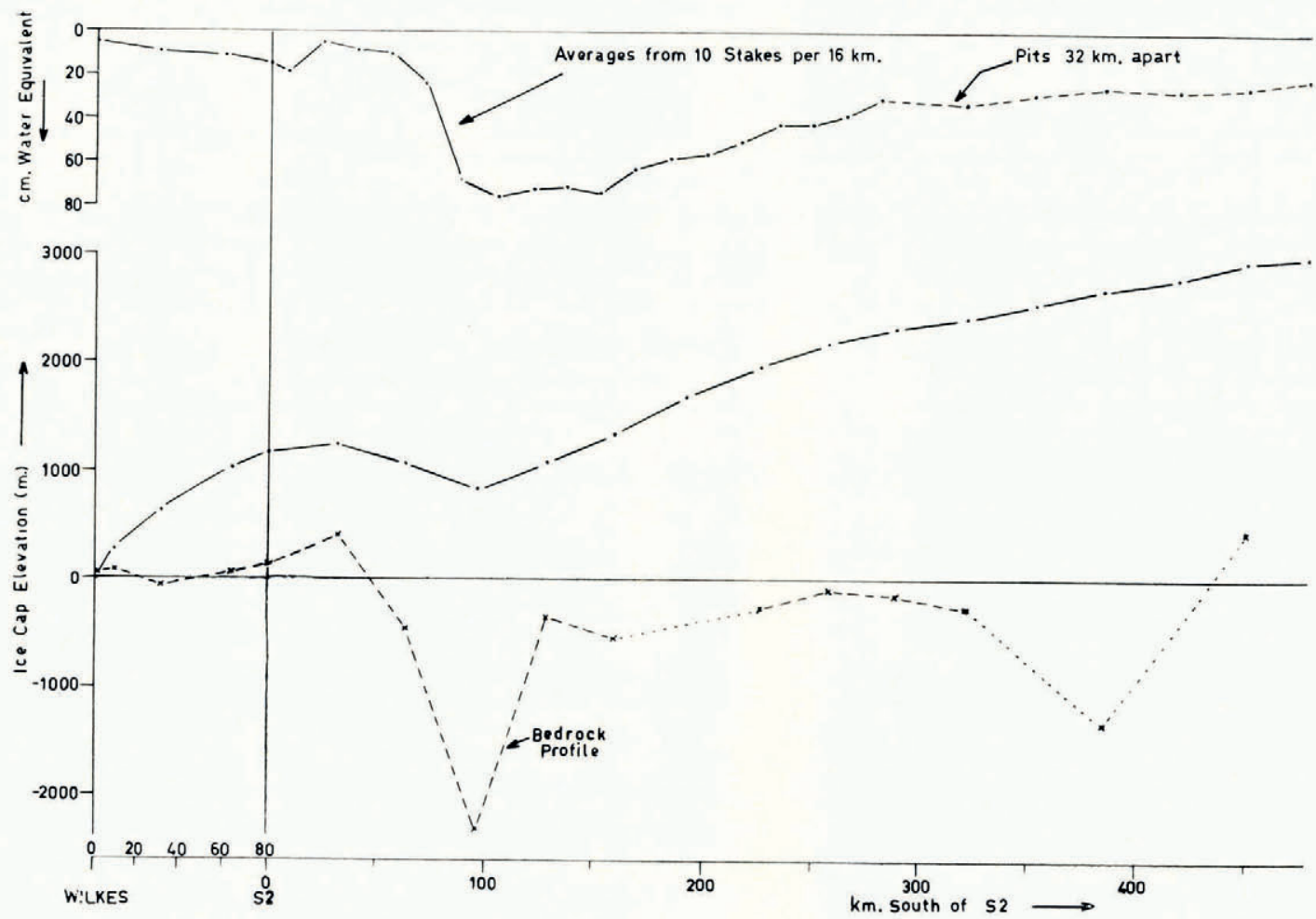

Fig. 5. Ice sheet profile from Wilkes east-south-east to station $S_{2}$ and south to lat. $7 I^{\circ} S$. along the traverse route of Figure $I$. Above this is shown the net accumulation profile over this route for November 1960 to November $196 I$. Values are taken from the average of $I 0$ stakes per ${ }_{1} 6 \mathrm{~km}$. from station $S_{2}$ to $290 \mathrm{~km}$. south, and from data from pits $32 \mathrm{~km}$. apart from 290 to $430 \mathrm{~km}$. south of station $S_{2}$. The bedrock profile is taken from fewell (unpublished)

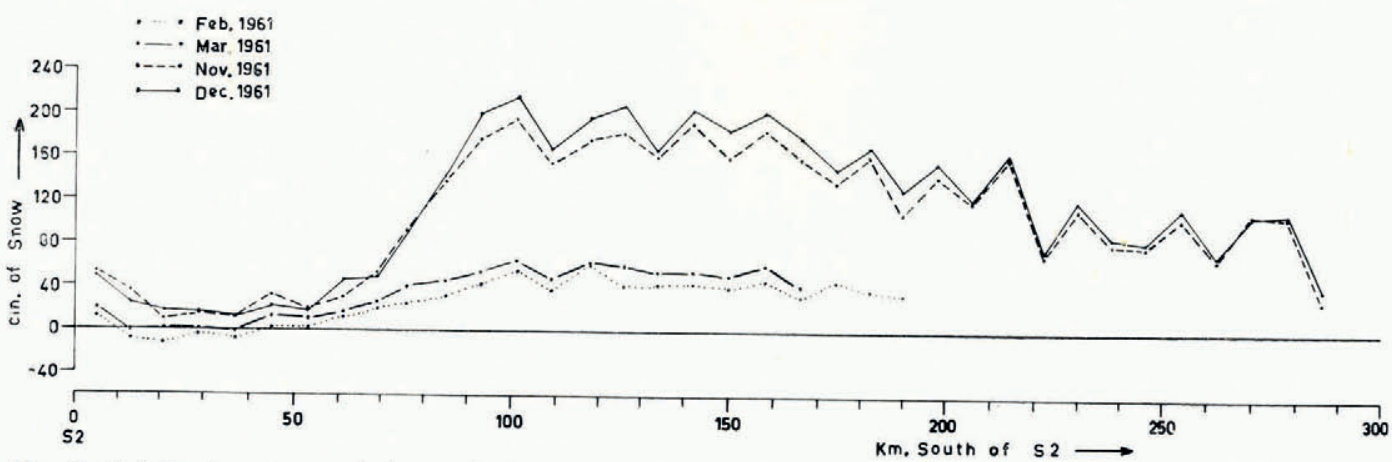

Fig. 6. Variation in net accumulation south of station $S_{2}$ during the year. The net snow accumulation from November 1960 is plotted for the four measurements of 1961 . The results are from the average of five stakes each $8 \mathrm{~km}$. The origin is
November 1960 
a series of irregular undulations of wave-lengths 5 to $15 \mathrm{~km}$., and amplitudes 7 to $50 \mathrm{~m}$. (Fig. 7). These undulations caused large variations in net accumulation (up to $215 \mathrm{~cm}$. in $3 \mathrm{~km}$.) with remarkable regularity.

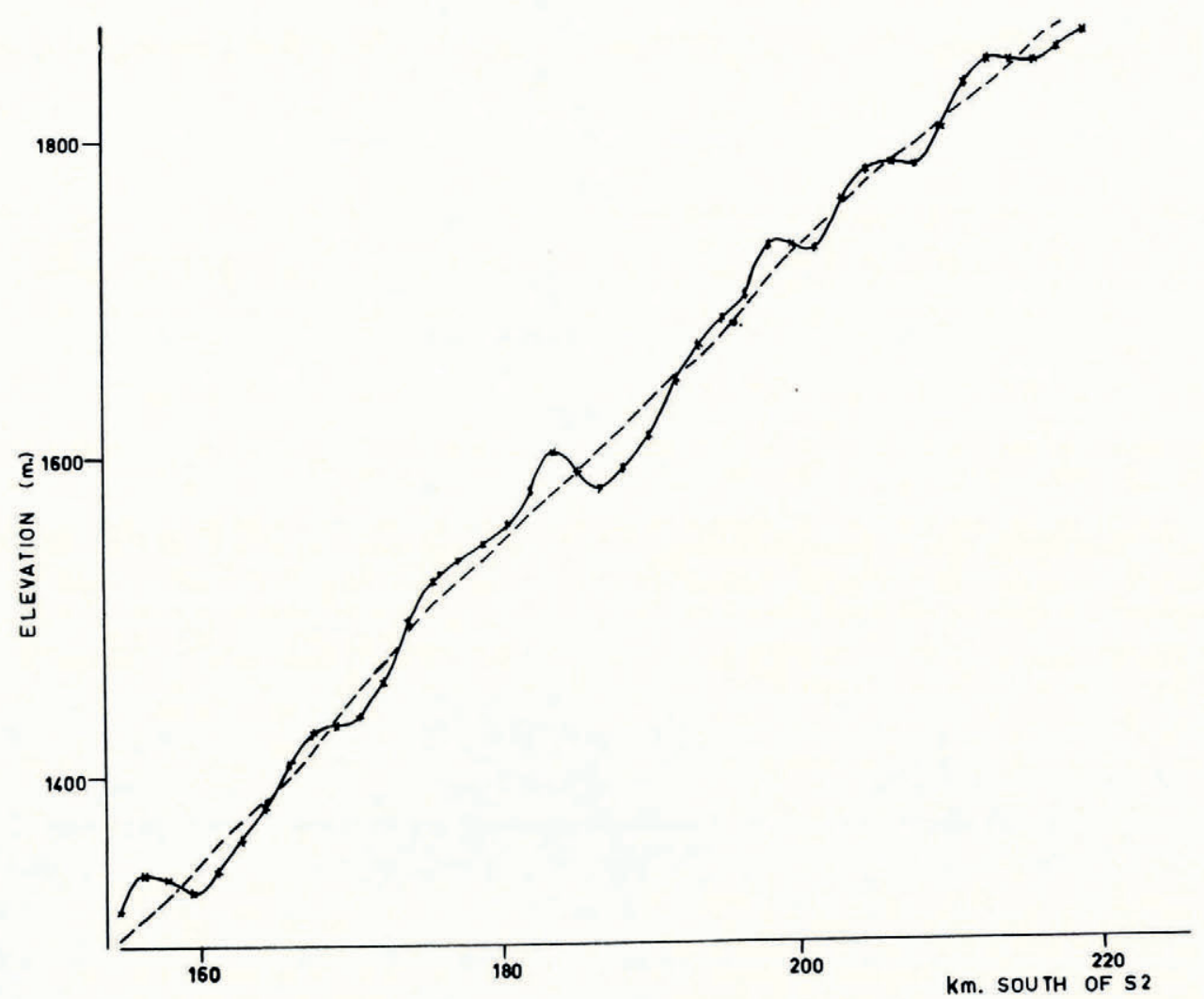

Fig. 7. Undulations on a steady slope. Between 150 and $200 \mathrm{~km}$. south of station $S_{2}$ the elevation for each mile $(1.6 \mathrm{~km}$.) position is plotted. The broken line has been obtained from the 10 mile $(16 \mathrm{~km}$.$) running-mean elevation$

Dolgushin (I96I) reported similar "waves" along a $150 \mathrm{~km}$. profile between Mirny and "Pionerskaya". These were observed to be between 2 and $6 \mathrm{~km}$. wide, perpendicular to the dominant direction of the wind, and to move slowly in the direction of the wind. In Terre Adélie, from the coast to "Charcot", a distance of $500 \mathrm{~km}$., accumulation was observed to vary greatly with local changes in slope (Cornet and others, 1960). Swithinbank (1959) reported a series of stepped ridges on a slope inland of Maudheim. Accumulation variations over these were found to be of the same order as those south of station $\mathrm{S}_{2}$. The accumulation stakes were too widely spaced to give an accurate picture of the net accumulation over these stepped ridges but Swithinbank noted that net accumulation appeared to be greatest where the slope was least. He concluded that eventually there would be a gradual smoothing of the topography but that owing to movement the irregularities would persist (Swithinbank, I 959, p. I34).

After comparing the accumulation data south of station $\mathrm{S}_{2}$ with the elevation profile, it appeared that net accumulation maxima occurred near the bottom of depressions and minima occurred near the crests. However, closer analysis revealed that the net accumulation 
profile is more closely related to slope. A comparison of profiles $\mathrm{I}$ and 2 in Figure 8 shows that net accumulation minima tend to occur down-wind of the tops of the crests, and the net accumulation maxima down-wind of the troughs.
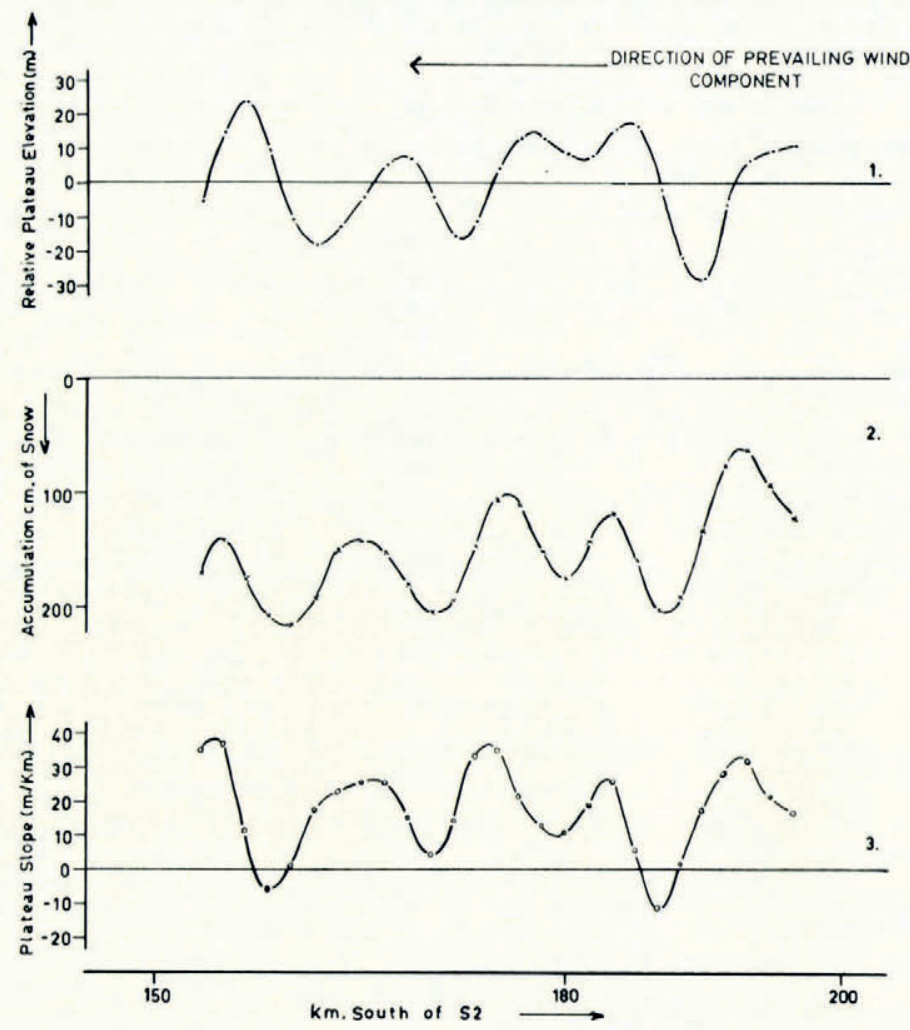

Fig. 8. Accumulation over an undulating slope. For a typical section of the traverse route in the region of high accumulation the following are plotted: (I) Relative elevation, obtained from the difference between the elevation at each stake and the Io mile $(16 \mathrm{~km}$.$) running mean (which represents the steady slope upon which the undulations are superimposed). (2) Annual net$ snow accumulation for each stake. (3) The average slope at each stake position. Each profile has been smoothed according to

$$
X_{i}^{\prime}=\frac{X_{i-1}+2 X_{i}+X_{i+1}}{4}
$$

Comparing profiles 2 and 3 , it may be seen that the net accumulation profile closely follows slope, not only in phase but also in relative magnitude. By least squares linear regression, the following expression has been found for the deviation in accumulation, $A$, from its mean in terms of the deviation in slope, $S$, and deviation in relative elevation, $E$ (units used as in Figure 7):

$$
A=-0.85 S-0.21 E .
$$

This suggests that rather than being filled in by the high accumulation the "waves" would advance up-slope, into the wind (in contrast to those reported by Dolgushin (I96I)).

If it is assumed that the accumulation does not destroy the waves but just causes them to advance up-slope at a constant rate, together with an overall rise of the surface, then an estimate of the rate of movement may be made in terms of the variation of accumulation over a wave and the corresponding variation of slope. 
For, suppose a series of waves is moving up a uniform slope at a constant speed, $v$, then the profile at a time, $t$, may be represented by an equation of the form:

$$
y=A x+B t+f(x-v t)
$$

where $x$ and $y$ are the horizontal and vertical coordinates of the profile,

$A$ is the uniform slope (assumed constant),

$B$ is the overall average rate of net accumulation of the surface as a whole, and

$f$ is a continuous periodic function with a continuous derivative and with zero integral over a period,

e.g. for a series of regular waves of amplitude $a$ and wave-length $\frac{2 \pi}{p}$,

$$
f(x)=a \sin p x .
$$

Then the accumulation rate is given by

and the slope by

$$
\frac{\partial y}{\partial t}=B-v f^{\prime}(x-v t)
$$

$$
\frac{\partial y}{\partial x}=A+f^{\prime}(x-v t) .
$$

Hence,

$$
\frac{\partial y}{\partial t}=B+A v-v \frac{\partial y}{\partial x} .
$$

This implies that the variation in net accumulation rate over the "waves" is proportional to the variation in slope. This appears to be in agreement with the net accumulation results obtained and is a condition for the preservation of the form of the waves.

To obtain $v$ we note that over any wave

$$
\left(\frac{\partial y}{\partial t}\right)_{\min .}-\left(\frac{\partial y}{\partial t}\right)_{\max .}=-v\left[\left(\frac{\partial y}{\partial x}\right)_{\max .}-\left(\frac{\partial y}{\partial x}\right)_{\min .}\right] .
$$

Over the region considered in Figure 8 the average variation in net accumulation over a wave was $83 \mathrm{~cm}$. of snow, and the average change in slope was $\frac{31}{1000}$. Hence, an estimate for $v$ (in $\mathrm{m} . / \mathrm{yr}$.) is given by

$$
0 \cdot 83=v \frac{31}{1000} \quad \text { or } v=27 \mathrm{~m} . / \mathrm{yr} \text {. }
$$

To obtain a more exact relationship for the variation of net accumulation over an undulating slope and to test the rate of movement it would be desirable to have a series of closely spaced stakes over a complete "wave". The study of the variation of drift transport with wind and the variation of wind down an undulating slope is expected to throw light on the cause of these phenomena.

\section{Conclusion}

\section{Annual net accumulation}

The Wilkes area from the coast to about $560 \mathrm{~km}$. inland may be considered in four main regions with merging boundaries.

(i) Within about $15 \mathrm{~km}$. of the coast, or below about $35^{\circ} \mathrm{m}$. elevation there is a region of very small net accumulation over the longer period, because the annual net accumulation varies from positive to negative values in different years.

(ii) From the coastal region going inland to about $100 \mathrm{~km}$. the net accumulation rate since 1957 increases from about $10 \mathrm{~g} . \mathrm{cm} .^{-2} \mathrm{yr}^{-1}$ over most of the slope to $\mathrm{I} 4 \mathrm{~g} . \mathrm{cm} .^{-2} \mathrm{yr} .^{-1}$ in the vicinity of station $\mathrm{S}_{2}$. 
(iii) Farther south from station $\mathrm{S}_{2}$ over a topographical depression and up the following slope there is a region of very high annual net accumulation with averages from 80 to $68 \mathrm{~g} . \mathrm{cm} \cdot .^{-2}$ between 90 and $200 \mathrm{~km}$. south of station $\mathrm{S}_{2}$.

(iv) Still farther south of station $\mathrm{S}_{2}$ the annual net accumulation decreases gradually to about $18 \mathrm{~g} . \mathrm{cm} .^{-2}$ by lat. $7 \mathrm{I}^{\circ} \mathrm{S}$., at an elevation of $3,000 \mathrm{~m}$., beyond the zone of strong surface winds.

\section{Variation in accumulation rate during the year}

The pattern of accumulation during the year is characterized by a period of rapid accumulation, autumn to spring, but net ablation during the summer. This net summer ablation varies from about $8 \mathrm{~g} . \mathrm{cm} .^{-2}$ at the coast to $2 \mathrm{~g} . \mathrm{cm} .^{-2}$ I $00 \mathrm{~km}$. inland, at an elevation of $\mathrm{I}, 200 \mathrm{~m}$. In the region farther south there was no net ablation over summer (November to March) but the accumulation rate was only about two-thirds of that from March to October.

\section{Topography influence} scales.

The accumulation pattern is strongly influenced by topography on both large and small

On the large scale the accumulation profile suggests that concave depressions gain accumulation at the expense of convex rises.

On the small scale, "waves" on a slope cause net accumulation maxima near points of least slope (including negative values) and minima near points of maximum slope. This should perpetuate the waves, but move them up-slope, into the wind, at a rate of the order of $25 \mathrm{~m}$./yr., for the slopes and accumulation rates observed inland.

\section{Acknowledgements}

The authors wish to acknowledge the support of all A.N.A.R.E. members who have helped with the projects, Mr. J. Hollin and Dr. R. L. Cameron for supplying detailed information of the 1957-58 work, and to Dr. U. Radok of the Department of Meteorology, University of Melbourne, for his advice and suggestions.

\section{MS. received 29 Jamuary 1963 and in revised form 8 June 1.963}

\section{REFERENCES}

Cameron, R. L., and others. 1959. Wilkes Station glaciological data, 1957-1958, by R. L. Cameron, O. Loken and J. R. T. Molholm. Ohio State University Research Foundation. Report 825-1-Part III.

Cornet, A., and others. 1960. Accumulation de neige en Terre Adélie, [par] A. Cornet, C. Lorius, G. Ricou. La Méléorologie, Sér. 4 , No. 57, p. $171-84$.

Dingle, W. R. J., and Radok, U. 1961. Antarctic snow drift and mass transport. Union Géodésique et Géophysique Internationale. Association Internationale d'Hydrologie Scientifique. Assemblée générale de Helsinki, 25-7-6-8 196o. Colloque sur la glaciologie antarctique, p. 77-87.

Dolgushin, L. D. 1961 . Zones of snow accumulation in eastern Antarctica. Union Géodésique et Géophysique Internationale. Association Internationale d'Hydrologie Scientifique. Assemblée générale de Helsinki, 25-7-6-8 1960. Colloque
sur la glaciologie antarctique, p. 63 -7o.

Hollin, J. T., and Cameron, R. L. 1961. I.G.Y. glaciological work at Wilkes Station, Antarctica. Journal of Glaciology, Vol. 3, No. 29, p. 833-43.

Hollin, J. T., and others. 1961. Wilkes Station glaciology, 1958, by J. T. Hollin, C. Cronk and R. Robertson. Ohis State Unicersity Research Foundation. Report 825-2-Part X.

Jewell, F. Unpublished. Wilkes ice thickness measurements, ig6r. Australia. Dept. of National Development. Bureau of Mineral Resources, Geology and Geophysics, Records, 1962/162.

Lorius, C. 1962. Contribution to the knowledge of the Antarctic Ice Sheet: a synthesis of glaciological measurements in Terre Adélie. Journal of Glaciology, Vol. 4, No. 31, p. 79-92.

Mather, K. B. 1962 . Further observations on sastrugi, snow dunes and the pattern of surface winds in Antarctica. Polar Record, Vol. 11, No. 71, p. 158-71.

Swithinbank, C. W. M. 1959. Glaciology. I. The regime of the ice sheet of western Dronning Maud Land as shown by stake measurements. Norwegian-British-Swedish Antarctic Expedition, 1949-52. Scientific Results (Oslo, Norsk Polarinstitutt), Vol. 3, E, p. 121-44. 